УДК 930.85(477.4/.5:477.8)"188/191"'(045)

ORCID ID: 0000-0003-0518-4796

Кушинська Лариса Анатоліївна, кандидат історичних наук, доцент, доцент кафедри суспільних наук. Київський національний університет театру, кіно і телебачення імені І. К. Карпенка-Карого, Київ

Кушинская Лариса Анатольевна, кандидат исторических наук, доцент, доцент кафедры общественных наук. Киевский национальный университет театра, кино и телевидения имени

И. К. Карпенко-Карого, Киев

Larysa Kushynska,

Ph.D of Historical Sciences, Associate Professor, Associate Professor of the Social

Sciences Departament. Kyiv National

I. K. Karpenko-Karyi Theatre, Cinema and Television University, Kyiv

\title{
КУЛЬТУРНИЙ ДІАЛОГ ПІДАВСТРІЙСЬКОЇ ТА НАДДНІПРЯНСЬКОЇ УКРАЇНИ ЗЛАМУ ХІХ-ХХ СТОЛІТТЯ
}

Анотація. Статтю присвячено співпраці й творчим контактам інтелігенції обох частин України на модерністському етапі вітчизняного відродження. Аналізується просвітницька діяльність нашої богеми, іiї культуротворчий потенціал. Відзначено вирішальну роль вітчизняної інтелігенції у формуванні української національної самосвідомості. Звернено увагу на проблему ідентичності української культури з огляду на відсутність державності та усвідомлення соборності на ментальному рівні й подальше втілення цієї ідеї у мистецьких творах. Співпраця української інтелігенції, ії контакти, а також просвітницька діяльність авторка розглядає як вирішальний чинник і предтечу соборності Україні.

Ключові слова: культурний діалог, національна свідомість, соціальна пам'ять, культуротворчий чинник, популяризація української культури, наукові товариства, творчі контакти, соборність України.

Постановка проблеми та ї̈ актуальність. Феномен українців двох імперій, що формально були іноземцями, усвідомлення їх культурної та духовної єдності, яку навіть конфесійний чинник не зміг розділити, заслуговує на увагу як істориків, так і з точки зору культурології та соціальної антропології. Часові рамки «зламу століть» відповідають періоду від останньої чверті XIX століття до початку Першої світової війни, що $\epsilon$, за визначенням I. Лисяк-Рудницького, модерним етапом української історії. Погоджуючись із дослідником щодо інтелектуальної амбівалентності українців, звертаю увагу на паралельний процес - закладання підвалин української єдності.
Зважаючи на історичний контекст, за якого на зазначений період не було сформованої численної української національної буржуазії, здатної економічно забезпечити розвій вітчизняної культури, варто особливо наголосити епохальну роль інтелігенції, котра не могла розраховувати на фінансове сприяння, а покладалася суто на добру волю небайдужих. Окремі меценати, Г. Галаган, Б. Ханенко, Н. Терещенко, В. Тарновський, Н. Яшвіль, І. Шараневич та інші допомагали розвиткові освіти, культури і мистецтв, однак кількість таких була нечисленною.

На зламі століть між інтелігентами й просто небайдужими обох окупованих частин України 
пожвавлюються контакти, на новий рівень виходить усвідомлення історичної, культурної, ментальної єдності, а також, політичних прав, що спричиняється до появи спільних наукових і культурних проєктів, а згодом - політичних партій. Відтак обопільний культуротворчий процес стає незворотним. Зважаючи, що предметом дослідження є контакти інтелігенції, якій історично судилося бути проводом нації, питання набуває особливої актуальності також виходячи 3 викликів XXI століття, як-от переосмислення історичних подій, боротьба за історико-культурну спадщину, повернення втрачених пам'яток культури і мистецтва тощо.

Одним 3 перших на порядку зазначену проблематику було поставлено основоположником української політичної географії, етнографом С. Рудницьким. Вчений вказував на відсутність в української інтелігенції здорової національної свідомості та на слабку загальну їі освіту, що й було причиною втраченого шансу державної самоорганізації. Тією чи іншою мірою зазначена тематика була предметом наукового розгляду таких вітчизняних і зарубіжних дослідників, як I. Лисяк-Рудницький, С. Рудницький, М. Семчишин, Б. Гаврилишин, О. Ганусин, І. Дзюба, I. Гирич, I. Вівсяна, I. Андронова, Л. Ляпіна, Л. Скорич, а також шведської дослідниці Елеонори Нарвселіус та інших.

Авторка цієї статті розглядає діалог національної інтелігенції на модерному етапі не лише в контексті просвітницької їх місії, що також $є$ важливим, а й як предтечу української соборності. Крім того, подається авторське обгрунтування різниці між національною ідентичністю й національною свідомістю.

Mema cmammi полягає у визначенні рівнів співпраці й контактів української інтелігенції, аби шляхом аналізу фактів дати відповідь на запитання:

- Наскільки діяльність творчої меншості обох частин України вписувалась у світосприйняття загалу, чи потрібна вона була загалу?

- Чи простою була ця єдність? Чи не була прогресивна галицька чи наддніпрянська богема фатально відірваною від повсякденного життя?

- Наскільки контакти інтелігенції двох частин України вписувались у чинне законодавство обох імперій?

- Що гальмувало усвідомлення й розбудову української соборності й єдності?

Виклад основного матеріалу. На відміну від країн Західної Свропи, проводом української нації історично судилося бути інтелігенції. Національ- ної буржуазії, здатної просувати й відстоювати національні інтереси, в обох частинах України не було сформовано, що також відіграло свою негативну роль у вітчизняній історії. Національна інтелігенція, богема, завжди посідала особливе місце в долі українського народу. Адже така $\epsilon$, за визначенням Арнольда Тойнбі, тією «творчою меншістю», котра здатна прийняти виклик й дати на нього гідну відповідь, яка в кінцевому рахунку, буде індикатором конкурентності нації. Українська інтелігенція фактично виконувала просвітницьку місію, i, зрештою, діячам української культури належить вирішальна роль у відродженні української національної свідомості за розуміння того, що сама Україна у XIX столітті була поділена між двома імперіями.

Якщо національна ідентичність, як повсякденне усвідомлення власної належності до певного етносу й відмінності від інших, формується природним чином, національна свідомість явище більш складного високого формату. Таке полягає в духовній потребі нації пізнання свого історичного минулого, витоків своєї культури, усвідомлення своєї гідності й на основі цього в обгрунтуванні етносом свого права на існування як національної територіально-політичної одиниці. У більшості країн Західної Свропи подібними питаннями переймалась національна буржуазія, в чиї інтереси входило існування національних держав. В обох частинах України саме інтелігенція взяла на себе місію відродження національної свідомості.

Формування такої для України є історико-культурним феноменом, зважаючи, що внаслідок імперської політики у XVIII столітті вітчизняна еліта відхрестилася від національних інтересів, навіть не встигнувши сформуватись як клас. На імперському рівні було зроблено все, аби стерти історичну пам'ять про історичне минуле, i, здавалося б, не існувало жодних чинників і передумов для формування національної свідомості, однак саме така починає розвиватись у XIX столітті. Всупереч всім законам логіки й суспільного розвитку, зусиллями просвітників-інтелігентів.

Цьому сприяло пожвавлення контактів українців обох імперій, каталізатором чого був Емський указ 1878 року. Як зазначає Мирослав Семчишин,

Заборона українського друкованого слова спричинила те, що східно-українські діячі перенесли свою видавничу діяльність до Галичини, а якусь частину — до Чернівців на Буковині, i під- 
силили там український народницький табір саме в той час, коли там відбувалась боротьба з рутенською і москвофільською течіями. (Семчишин, 1985 , c. 315$)$

Об'єктивною реальністю було й лишається те, що будь-які наукові чи творчі здобутки ліпших представників нації без держави завжди збагачують саме імперську спадщину. Однак для української богеми відкривалася можливість таким шляхом привернути увагу до національної специфіки, історії, фольклору. А зрештою й до того, що серед імперських народів $\epsilon$ діячі, котрим небайдужа доля їх унікальної національної культури. Діалог на рівні образотворчого, театрального, музичного мистецтв популяризує українську тематику, надає їй нового звучання. Співпраця інтелігентів обох частин України виводить на новий рівень усвідомлення історичної, культурної, ментальної єдності, а також політичних прав, що спричиняється до появи політичних партій та їх програм. Відбувається відразу кілька важливих подій у обох частинах України. У Підавстрійській це початок діяльності Наукового товариства імені Шевченка, зокрема, видання «Записок Наукового товариства імені Шевченка», заснування українського часопису «Зоря». 3’їзд українських письменників, що відбувся у Львові в 1898 році з нагоди сторіччя виходу в світ «Енеїди» наддніпрянського письменника I. Котляревського, засвідчує становлення вітчизняної літературної спільноти та іiі готовність до подальшої просвітницької місії.

Роком раніше, як у Львові відбувався з'їзд письменників, у Києві в 1897 починає роботу Товариство старожитностей і мистецтв, з ініціативи якого засновано перший публічний музей у Києві. Серед учасників товариства відомі історики, етнографи, краєзнавці, педагоги, як-от В. Антонович, I. Огієнко, М. Василенко, О. Левицький та інші. Починаються перші цілеспрямовані контакти науковців обох установ - відомо, що підтримував такі з Науковим товариством імені Шевченка у Львові, а потім у 1910 році став його почесним членом Орест Левицький. На громадську арену виходять відомі українські діячі: Іван Франко, Михайло Павлик, Михайло Драгоманів, Наталя Кобринська та ін.

Національне законодавство імперій, під юрисдикцією яких перебували українські землі, по-різному сприймало прояви національно-свідомих настроїв в українському середовищі. У Імпеpiї Габсбургів Конституційний закон 1867 р. проголошував рівність усіх громадян перед законом, однакову доступність державних посад для всіх осіб, які мають австрійське підданство, рівність у правах усіх народів держави, невід'ємне право кожної нації підтримувати і культивувати свою національність і мову, визнання державою за всіма мовами, вживаними в областях монархії, рівного права на використання у школах і при здійсненні функцій та різноманітних актів державного життя. Важливим було положення про організацію установ народної освіти в областях, населення яких належить до різних народностей, про право кожної з них отримувати освіту власною мовою.

У Російській імперії не існувало конституційних законів і гарантій прав, натомість до початку XX століття діяв Емський указ 1876 р., що доповнював Валуєвський циркуляр 1863 р. 3 одного боку, такий мав стати гальмом на шляху відродження української культури, але на практиці спричинився до протилежного результату.

Різними були й опоненти. Скажімо, якщо в багатонаціональній, але конституційній і парламентській Імперії Габсбургів головним опонентом була реакційна частина польської національної громади, то у Російській імперії, за відсутності конституції і парламенту, авторитарне правління вороже сприймало будь-що, не співзвучне офіційній політиці.

Відтак українські інтелігенти обох імперій перебували у неоднакових умовах, їх практичні можливості реалізації власного наукового й творчого потенціалу були різними. У Російській імперії університети не мали того досвіду полеміки та наукових дискусій, як, скажімо, у Західній Європі, тут не шанувались ідеї раціоналізму й гуманізму, а самі заклади, головним чином, планувались як осередки імперської політики. Багатьох відомих науковців виключали з числа студентів за вільнодумство чи й за організацію гуртка української мови, як те сталося з відомим українським правником і соціологом Богданом Кістяківським. Науковець, якого вважають першим марксистом, переїхав до Галичини, однак його візит викликав підозри вже австрійських правоохоронців, тож, спроба налагодити співпрацю з М. П. Драгомановим була не настільки успішною. У Б. Кістяківського було чимало літератури, забороненої цензурою Російської імперії, тож його поневіряння тривали.

В Австрійській імперії, до якої належала Галичина, не було заборони на українські товариства. Судячи 3 тих, що брали участь у Галицькій крайовій виставці 1894 року, функціонували «Боян», «Зоря», «Дністер», «Народна Рада», «Народна торгівля», «Наукове товариство імені 
Шевченка», «Просвіта», «Руська бесіда», «Руське педагогічне товариство», «Товариство для розвою руської штуки» та інші. Цього ж року, коли русинська громада отримала можливість відстоювати свої освітні права, у Львівському університеті було відкрито кафедру історії України, більш відому як кафедра всесвітньої історії з особливою угодою до Східної Європи. Через шість років розпочала роботу кафедра української мови та літератури і церковнословянської мови. У Підавстрійській Україні відомі співвітчизники отримували визнання після Львівського, Ягеллонського чи Віденського університетів, а їх твори ставали відомими у світі. Випускниками Віденського університету були письменник Іван Антонович Крушельницький, поет Іван Якович Франко, винахідник X-променів Іван Павлович Пулюй, режисер та драматург Лесь Курбас, юрист і громадський діяч Теофіл Окуневський, виконувач обов'язків міністра закордонних справ УНР у 1919-1920 роках Володимир Якимович Старосольський та інші відомі діячі.

Отримуючи освіту у імперських університетах, перебуваючи в іншомовному середовищі, українська інтелігенція не могла уникнути певного тяжіння до імперської культури, однак, попри це, відчутна ії частина розуміла необхідність відродження й популяризації саме культури української. Науковці Наддніпрянської України здебільшого ставали відомими після визнання Петербурзькою Академією Наук. Людмила Старицька-Черняхівська, письменниця Наддніпрянської України, згадувала:

Наше покоління - виключне покоління: ми були першими українськими дітьми. Не тими дітьми, що виростають в селі, в рідній сфері стихійними українцями, - ми були дітьми городянськими, яких батьки виховували вперше серед ворожих обставин свідомими українцями 3 сповитку/ (Слобожаніна, 2018)

Дуже схожими є роздуми відомої буковинської письменниці, Євгенії Ярошинської: «Моє образованє було виключно німецьке, бо хоть в нашім домі говорилось по-руськи, то, пішовши до шкіл в Чернівцях, не чула-м нічого про руськість, бо там все було німецьке». Літературний дебют більшості підавстрійських письменників відбувався німецькою мовою, такими були I. Франко, О. Кобилянська, Є. Ярошинька.

Негативний вплив іноземного оточення добре розуміли українські інтелігенти й обурювалися 3 того приводу. Борис Грінченко один з небагатьох, хто усвідомлював нагальну необхідність саме української освіти, виступав за послідовне проведення культурно-просвітницької роботи в українському суспільстві і розумів важливість діалогу 3 австрійськими українцями. Його «Листи 3 України Наддніпрянської», надруковані у газеті «Буковина» 1892-1893 рр., були не лише політичним оглядом, а радше зверненням до українців іншої держави. Твір сповнений критики та відчаю.

Інтелігенція вся у нас змоскалена. Вчиться вона по-московському, читає по-московському, завсігди говорить сама і завсігди чує круг себе мову тільки московську; рідну ж мову в мужичих устах вважає за "хахлацкій жаргон". Історичних українських традицій ніяких - замість них або московський патріотизм, або нічого не вартий хисткий та мінливий лібералізм, або просто ніщо: їсть, п’є, спить, читає, ходить у театр людина, та й годі, та й більш нічого, ніяких принципів. Відкіля ж тут візьметься національне самопізнання? Як дійде до нього людина? Звичайно робить се Шевченко або яка інша вкраїнська книжка. Прочитає людина, і як ще не зіпсована, світла, щира, то спиниться. Вразить іiї краса, правда. Почне думати... Почує, може, випадково, яке прихильне слово про те, над чим спинилася... Прокидається і в самої прихильність. Якщо обставини не будуть ворожі виразно такому напрямку, то раз розбуджена думка ітиме й далі тим же шляхом; здебільшого ж обставини бувають ворожі, і думка потроху завмирає i, нарешті, зовсім умира. (Грінченко, 2013: 32)

Листування Б. Грінченка і М. Драгоманова, втілившись у творах «Листи з України Наддніпрянської» і «Листи на Україну Наддніпрянську» дало не лише умовну назву певній частині єдиної нині держави, але й свідчило про усвідомлення письменниками нагальної необхідності гуртування зусиль для просвітництва й єднання. Обидві праці містять грунтовну аналітику стану української культури, а також іiі місця у загальному світовому спадку. Застерігають проти небезпеки «обмоскалення». Зосереджують увагу поклику української інтелігенції щодо просвітництва, зазначаючи при цьому що сама така не завжди усвідомлює свою мету й органічно тяжіє до імперського формату (Діалоги, 1994, с. 11).

Братство Тарасівців, що виникло на знак протесту проти русифікації, свої програмні документи, в обхід цензури, змушене було друкувати у австрійському на той час Львові, в журналі «Правда» під назвою «Profession de foi молодих українців». Віталій Боровик, один з фундаторів Братства, член гуртка «Плеяда», підтримував дружні 
стосунки з Василем Стефаником. За злою іронією Історії, політично неблагонадійний у Російській імперії, тобто ворожий до царського режиму, Вiталій Боровик став жертвою сталінських репресій у 1937 році, що вкотре доводить суть більшовицької політики.

Найпродуктивнішим результатом як двосторонніх контактів інтелігентів двох частин України, так і їх цілеспрямованої наукової і просвітницької діяльності з чіткою метою, планом, стратегією, визначеними завданнями можна вважати Наукове товариство імені Шевченка у 1873 р. Через два роки на політичну арену виходить молодий Іван Франко, котрий запрошує до співпраці Михайла Драгоманова, наддніпрянського соціолога, і разом 3 Михайлом Павликом вони, насамперед, відкидають штучне язичіє й запроваджують живу народну мову, що виводить вітчизняну журналістику й пресу на якісно новий рівень. Друковані видання охочіше купують.

Однак залишалося відкритим питання створення загальноукраїнського журналу, який міг би об'єднати письменників з обох частин України, підняти на своїх сторінках актуальну проблематику, стати, таким чином, загальнонаціональною трибуною передових літераторів. За останню чверть XIX ст. було кілька спроб створити таку загальну трибуну письменників-літераторів. Письменниця, засновниця феміністичного руху Галичини Наталя Кобринська активно співпрацювала з Оленою Пчілкою і Ганною Барвінок, внаслідок чого з львівської друкарні Наукового товариства імені Шевченка у 1887 році виходить жіночий альманах «Перший вінок». Унікальність збірки не лише в тому, що вона дала можливість друкувати свої твори талановитим письменницям, поетесам 3 обох частин України i, таким чином, реалізовувати свій творчий потенціал. Серед творів - проза, статті, вірші, де розкривається далеко не лише лірична тематика. Чимало дописів присвячені актуальним злободенним питанням, більше того, чітко усвідомлюється важливість єднання. Олена Пчілка у своєму вірші «Перший вінок» саме й закликає:

До спілки ж, сестри! В нашім гаю

Вінки ми праці пов'ємо -

I на користь рідного краю

Жіноче серце віддамо!

Ії̈ ж твір «Дебора» оповідає не лише про біблійну пророчицю, ім'я якої й означає «пчола», а висвітлює тему заклику до боротьби проти іноземного поневолення, готовність взяти персональну участь у цій боротьбі й місію жіноцтва в епохаль- них битвах історії (Тридцять українських поетес, 1968, c. 70)

У Наддніпрянській Україні в той час з ініціативи брата і сестри Косачів, Михайла й Лесі, було засновано літературний і просвітницький гурток «Плеяда». Його учасниками були відомі інтелектуали, письменники, науковці, історики: мовознавець-перекладач Євген Тимченко, мовознавець-історик Агатангел Кримський, один із засновників Братства Тарасівців Віталій Боровик, письменниця Людмила Старицька, поет і перекладач Максим Славинський та інші. Мовознавці й поліглоти перекладали українською мовою твори світової класики й мали стати трибуною нової української літератури. Проте блага мета виявилась небезпечною для Російської імперії, тож заборонений цензурою у 1889 році гурток припинив існування у 1893. Контакти наддніпрянців 3 письменниками й громадськими діячами Австрійської України тривали у Галичині, на рівні журналу «Зоря».

З 1890 року це видання публікує твори українських письменників i, по суті, стає загальноукраїнською літературною трибуною обох частин України. Саме завдяки «Зорі» у Галичині стало відомо про творчість Тараса Шевченка, а також інших поетів й письменників з Наддніпрянської України, скажімо, Панаса Мирного, І. Нечуя-Левицького, Олени Пчілки, Леоніда Глібова та інших. Публікацією у «Зорі» вірша «Надія» сімнадцятирічна Леся Українка розпочала свій творчий шлях. Журнал друкував як твори іменитих письменників, так став і стартом для тих, хто пробував свої сили, що дало можливість реалізувати творчий потенціал. Друкувалися твори в «Зорі» за 1886 рік мовою оригіналу — було надруковано вірш М. О. Некрасова «На смерть Шевченко» («Зоря», 1988-1989, с. 10). Відомими ставали твори М. Коцюбинського, П. Грабовського, О. Кобилянської, Н. Кобринської, Б. Грінченка, М. Черемшини.

Іван Франко працюючи у редакції «Зорі», вважав себе особою вельми солідного віку й зазначав, що погодився на те не 3 власної волі, а за порученням молоді. А молодому поколінню, його просвітництву письменник приділяв чималу увагу, від просвітницьких екскурсій історичними місцевостями Галичини до опіки над молодими літераторами «Покутської трійці». Ольга Кобилянська у 1890 році намагається познайомити галицького читача 3 наддніпрянськими письменниками, популяризувати їх твори. Саме з іiі ініціативи з'являється низка перекладів оповідань Марка Вовчка, а також стаття про саму наддніпрянську письменницю. 
Контакти на рівні літераторів тривали активно. Павло Грабовський, засланий до Сибіру за політичну неблагонадійність, надсилав власні й перекладені твори у Галичину, де пізніше вийшли друком збірки його віршів та перекладів «Пролісок», «3 чужого поля», «3 півночі». Микола Вороний, письменник, який за народницькі переконання не мав можливості вступити до Московського чи Санкт-Петербурзького університетів, начався у Львові та у Відні. У Львові знайомиться iз I. Франком, активно співпрацює 3 провідними українськими науковими, просвітницькими й мистецькими установами - Науковим товариством імені Шевченка, Театром Руської бесіди, а також у редакціях газет і журналів: «Зоря», «Життє і слово», «Громадський голос», «Радикал». Переймається тим, що українська спільнота віддаляється від свого національного коріння, присвячує цьому свою символічну поему «Євшан-зілля» про траву, котра повертає людям втрачену пам'ять. Крім того, був актором трупи М. Кропивницького та П. Саксаганського з 1897 року, коли Театр Корифеїв розпочав активні контакти з Театром Лаврівського.

Просвітницька робота української інтелігенції спрямовувалась насамперед на основну категорію населення обох частин України - консервативне селянство. Маючи можливість мандрувати країнами світу, українські діячі бачили прірву, яка відділяє українських селян, що ніби застигли у середньовіччі, від аграріїв інших країн. Нечисленні подвижники й меценати, розуміючи, що вбогість $є$ головною причиною політичної незрілості нації, самотужки намагались забезпечити освіту найбільш вразливих категорій українського населення, а також спростити шлях до освіти, науки й мистецтв талановитій українській молоді. Це було непросто, адже імперський формат освіти давав цензурі повний карт-бланш.

У Наддніпрянській Україні окремі подвижники, як-от Тадеуш Рильський, Христя Алчевська (відома народна школа Христини Алчевської, де вчителював Борис Грінченко), локально намагалися поліпшити життя селян - влаштовували їм школи, дбали про благоустрій сіл та селищ. У Колегії Павла Галагана навчались українці і з Австрійської імперії, працював Іван Франко. Христя Алчевська, письменниця, інтелектуалка, котра підіймала у своїх творах актуальну проблематику, листувалась із письменниками з Підавстрійської України - I. Франком, М. Павликом, В. Стефаником тощо. Отримавши вищу освіту за кордоном, досконала володіла французькою мовою. Розумі- ючи, що українці Російської імперії приречені на денаціоналізацію, працюючи у недільній школі, викладала українською мовою попри заборону. У 1915 р. на квартирі Христі Алчевської відновилися регулярні зібрання гуртка української молоді.

Просвітницька робота була непростою. Консервативні українські селяни мали свою специфіку - будучи до середини XIX століття фактично безправними й відтак відчуваючи свою відстороненість від громадських справ, цей суспільний стан вважав за ліпше не витрачати час і ресурс на те, у що вже не вірили. Слід нагадати, що селянська реформа в Імперії Габсбургів відбулась на чотирнадцять років раніше, аніж у Російській, й тривала поетапно й поступово, від кінця XVIII століття, починаючи від реформ Марії Терезії. Однак українські аграрії, байдужі до юрисдикції, історично прагнули хазяйнувати на власній землі. Йти у найми вважалося злою долею, а логістику реалізації своєї найсолодшої мрії люди не усвідомлювали. За таких реалій достукатись до селянства, аби те усвідомило власні політичні права, було справою непростою. Навіть отримавши можливість обирати й бути обраним у Імперії Габсбургів, селяни масово продавали свої голоси, це явище, відоме як «хрунівство», викликало обурення у свідомих галичан (Шеремета О., Шумлянський В.).

На зламі XIX й XX століття, політична й громадська незрілість галицького селянства стала очевидною для національної інтелігенції, котра збагнула, що просвітницька робота має спрямовуватись не лише на навчальні заклади, а й на загальний рівень усвідомлення власних прав, потреб, законних інтересів. Львівський часопис «Основа», намагаючись подолати вікову заскорузлість, зокрема, закликає:

Чи не потрібно нам наших купців, ремісників, промисловців? Хто спосібнійший, сего посилати рішучо до висших шкіл! У нас інтелігенції страх мало, а доки не будемо мати велику силу нашої рускої інтелігенції, доти будемо все слабшими. Не засиджуймось, не замикаймось в однім лише нашім селі непросвічені, темні, заскорузлі, а йдемо до просьвіти, в сьвіт, за ліпшею долею. (Основа, 1907, 10 липня)

На початку XX століття політична ситуація радикалізується, подібні настрої галицьких політиків непокоять українську громаду. Лівацьку ідеологію місцеве населення інстинктивно відкидало як чужу та ворожу щодо християнського світосприйняття. Часопис «Основа» спочатку засуджує ці явища, потім просто констатує: «...в Австрії 
соціялізм тепер в моді. Аж близько 90 відсотків соціялістичних послів увійшло до нового парляменту...». (Основа, 1907, 21 серпня). Доводиться констатувати, що у галицьких селян розуміння свого права на окремішнє існування як національної держави не набуло чітких обрисів приблизно так само, як і у наддніпрянських. У Підавстрійській Україні давались взнаки зерна полонізації, шанованим й бажаним лишався польський формат гречної поведінки, чому сприяло оточення. Адже адміністративні посади обіймали етнічні поляки, серед яких також щойно зароджувалось розуміння прав корінного етнічного населення Галичини. У Наддніпрянській Україні тривала цілеспрямована політика денаціоналізації й русифікації, конфесійний чинник в якій посідав окреме місце.

3 іншого боку, галичани усвідомлювали своє відчутно ліпше становище порівняно 3 побратимами із Російської імперії. У своїй рубриці «Що чувати в світі. 3 Росії» часопис висвітлював події культурного, політичного й громадського життя Наддніпрянської України, зокрема, засідання Державної Думи. Судячи 3 дописів, австрійські українці були добре обізнані зі специфікою життя сусідньої імперії, зокрема, становищем селян та станом їх політичних прав та свобод. Розуміючи залежність Держдуми, цього першого станово-представницького органу від милості російського імператора, «Основа» іронічно зазначає: «Дума ще не розігнана, радить» (Основа, 1907, 21 серпня).

Особлива увага у часописі приділяється роковинам Тараса Шевченка:

Сином тим рідним нашого народу $є$ Тарас Шевченко. Прийшов він у світ у селі Моринцях, звенигородського повіту в Київській губернії. Родичі його були убогі селяни-кріпаки. Цілу свою молодіж провів Тарас у великій нужді, аж коли дістався в Петербург і там земляки пізнали в ньому великі спосібності до поезії і до малярства. I став $з$ сеї селянської дитини з часом великий поет-віщун, котрий став співати своєму поневоленому народви про волю. Своїми могутніми піснями став будити руского велетня з вікового сну......... нарід руський як велика і широка Русь-Україна річ-річно поминає концертами свого великого генія, котрий жив для свого народу, бажав йому найбільше добра і терпів так багато за него. А пісні великого Кобзаря полинули могучею струєю в руский народ, розбудили його і оживили до нового життя. (Основа, 1907, 27 березня)

Взаємні контакти інтелігенції обох частин України також популяризували українську тематику у образотворчому, театральному, музично- му мистецтві. Тут звучала тема історії козацтва, Давньоруської держави княжих часів, що апелювало до спільного минулого та культурно-духовних цінностей. У образотворчому мистецтві піонерами української тематики були випускники Віденської Академії Мистецтв К. Устиянович та Т. Копистинський. Їх справу продовжили майстер історичного жанру М. Івасюк, Ю. Панькевич, Ю. Пігуляк, та інші. На Наддніпрянській Україні то С. Васильківський, М. Пимоненко, К. Трутовський, М. Мурашко, І. Їжакевич. Перший ректор Української академії мистецтва Федір Кричевський навчався у Густава Клімта, що вочевидь позначилось на його творчості.

Передова творча інтелігенція обох частин України також усвідомлювала свою просвітницьку місію й зазвичай вдало поєднувала творчість із громадською діяльністю. Зусиллями небайдужих представників богеми організовувались народні хорові товариства, здійснювались аматорські театральні постановки, що сприяло самоосвіті селян. Корнило Устиянович, захоплюючись генієм Тараса Шевченка, своїми працями популяризує Кобзаря у галицькому середовищі. Картина «Шевченко на засланні» передає характер поета, його сум за Батьківщиною, обурення з приводу придушення свободи у імперії, та ще доволі багату палітру почуттів. Погляд Тараса Григоровича ніби занурений у свій внутрішній світ, рука - на захалявній книжечці.

Юстин Пігуляк, перший в Буковині художник-професіонал, учасник і організатор Буковинського віча, учасник «Руської бесіди», популяризував тематику історії козаччини, поезій Тараса Шевченка. Картина «Дума про Україну» сповнена сюжетами з історії козацтва. Роботи Ю. Пігуляка відомі в Австрії, Канаді, Польщі, Румунії, Угорщині, наразі безслідно зникли і досі не знайдені. Відомий учень Юстина Пігуляка, Микола Івасюк, був майстром історичного жанру. Під час навчання у Віденській Академії мріяв намалювати картину з постаттю Богдана Хмельницького, що митцеві зрештою й вдалося. Більшість робіт Миколи Івасюка сьогодні - у приватних колекціях в Польщі, Австрії, Німеччини.

Важливою подією в галузі українського прикладного мистецтва у Галичині стало створення у 1898 році Товариства для розвою руської штуки. Співзасновниками були Іван Труш, Юліан Панькевич, Василь Нагірний та Михайло Грушевський, які подбали і про робочі місця, і про мистецьку школу на базі Товариства. Юліан Панькевич, відомий митець, був не лише людиною різнобічно ге- 
ніальною, але одним із небайдужих до стану розвитку селянства. Організовував у селах гуртки самоосвіти, аматорські вистави, для яких власноруч виготовляв костюми та декорації, керував хорами, безкоштовно навчав сільських дітей малюванню й історії мистецтва. Картина Ю. Панькевича «Сільська Мадонна» $є$ не лише свідченням високої майстерності художника, що отримав грунтовну європейську освіту, а й передає захоплення митця самою щирістю сільського життя, радості звичайної жінки з немовлям у красивому національному одязі, на задньому плані дбайливо виписано особливості галицької архітектури, в самій картині переважають світлі кольори. Наддніпрянські мотиви відтворені у картинах «Хмельницький закликає козаків на повстання» (1896), «Тарасове горе» (1903), «Подільський пейзаж», «Дніпро».

Іван Труш, підданий Імперії Габсбургів, органічно пов'язаний із Наддніпрянською Україною i родинними зв'язками, оскільки був одружений 3 кузинкою Лесі Українки, Аріадною Драгомановою, і ментально, адже писав портрети відомих інтелігентів. За дорученням НТШ Іван Труш виїхав на Наддніпрянщину 3 метою встановлення творчих контактів 3 місцевими діячами. Самого митця вважали імпресіоністом, однак сам себе Іван Труш ідентифікував як реаліст. Радше реаліст-мінімаліст, митець, що завдяки мінімуму ліній передавав максимум характеру.

Наприкінці XIX століття з ініціативи українського письменника Гната Хоткевича активізувався театральний діалог двох частин України. Було організовано гастролі його Гуцульського театру на Слобожанщині, а під час подорожі відбувались гуцульські вечори у Києві, Одесі, Херсоні та інших містах. Пожвавлюється інтерес до української музики, перша спроба перевести яку на академічний рівень була здійснена ще в у середині століття С. Гулаком-Артемовським. У 1884 році, вже після смерті композитора, Марко Кропивницький поновив було постановку раніше забороненої опери на базі трупи Михайла Старицького. Драматург продовжує українську історичну тематику, написавши лібрето на твори М. Гоголя «Тарас Бульба» та I. Котляревського «Наталка Полтавка», прем'єра якої відбулась у Одеській опері у 1889 році.

Музику до зазначених опер пише Микола Лисенко, який, попри шалену цензуру, робить усе для популяризації української музики, української історії та створення відповідних організацій. Зацікавившись співом відомого кобзаря Остапа Вересая, композитор на його прикладі досліджує специфіку народної музики. Згодом на відкрит- ті Колегії Галагана М. Лисенко виступає з доповіддю «Характеристика музичних особливостей українських дум і пісень, виконуваних кобзарем Вересаєм», в якій по суті підносить народний кобзарський спів на рівень наукового дослідження. Філарет Колеса, відомий галицький історик, етнограф, фольклорист, дійсний член Етнографічної комісії львівського Наукового товариства імені Шевченка, у 1908 році здійснив етнографічну експедицію на Наддніпрянську Україну з метою збирання, записування, а також популяризації традицій музики кобзарів і лірників. Леся Українка та Климент Квітка, усвідомлюючи важливість як самого дослідження, так і живого контакту, пожертвували на подію власні кошти. Оскільки мандрувати селами Наддніпрянської України було не вільно, дослідник робив записи у Миргороді. Його роботу продовжив відомий наддніпрянський маляр і етнограф Опанас Сластіон.

Оперна музика Підавстрійської України була більш орієнтована на західноєвропейського поціновувача. Віденська опера сприймалась як трибуна для провідних композиторів Європи, тож українська народна тематика тут була менш популярною. Однак відомі композитори, котрі своїми творами популяризували саме українську музику, надаючи їй академічного рівня, а також поширювали у своїх творах історичну тематику. Анатоль Вахнянин, Денис Січинський були засновниками музичного товариства «Боян», сама назва якого апелює до давньоруського епосу. Відома опера А. Вахнянина «Купало» до драми забороненого Т. Шевченка «Назар Стодоля», «Бондарівна» на історичну драму Федора Заревича. Денис Січинський, автор гімну «Не пора», написав історичну оперу «Роксолана». Василь Барвінський, відомий композитор з Підавстрійської України, у 1914 році написав фортепіанний твір, присвячений пам'яті Миколи Лисенка. Це були практичні кроки усвідомлення історичної й духовної єдності українськими композиторами, що дало поштовх для поширення цієї думки.

Таким чином, за імперської юрисдикції українська інтелігенція Підавстрійської і Наддніпрянської України, громадські діячі, політики, митці докладали всіх зусиль для просвітництва і популяризації української культури, не обмежуючи свою діяльність суто науковим чи мистецьким пошуком. Завдяки їх співпраці стають можливими друк української літератури, популяризація історії та культури, зрештою, репрезентація такої на світовому рівні. 
Українська тематика у драматичних, літературних чи мистецьких творах привертала увагу своєю новизною. У зазначений період бажання обопільної співпраці і взаємна зацікавленість у подальших контактах були результативними й очевидними, що дає підстави розглядати міжкультурні контакти і сам культурний діалог як чинник подальшої соборності України. Позитивна тенденція, на жаль, була перервана Першою світовою війною. Актуальними виявилися слова С. Рудницького про те, що без національної української держави доживемо у найближчий час до нових тяжких воєнних і революційних катастроф (Рудницький, 1916).

Здійснюючи культурно-просвітницьку місію, українська інтелігенція 3 часом стала тим небезпечним класом, на який спрямувалася політика знищення. Спроба продовжити діалог культур під час політики українізації стане трагедією українського народу. Більшість українських діячів 3 обох частин України, які спрямовували зусилля на формування свідомості нації, стали жертвами сталінського терору. Це українознавець і засновник української політичної географії Степан Рудницький, відомі режисери Лесь Курбас, Гнат Хоткевич, художник Микола Івасюк, історики Михайло Грушевський, Катерина Грушевська, письменники Ісидора Косач, Климентій Квітка, Марія Старицька-Черняхівська, засновник Братства тарасівців Віталій Боровик та ще тисячі українських інтелектуалів.

Сьогодні тривають два паралельні процеси 3 одного боку, Україна $є$ незалежною державою й усі перепони формально подолано. Належну оцінку отримала також культуротворча місія української інтелігенції. При цьому даються взнаки окремі моменти світосприйняття, ідеології, зрештою, культури.

\section{Висновки:}

- На модерному етапі вітчизняної історії інтелігенція обох частин України, виконуючи просвітницьку роботу, достатньо визріла для ролі національної еліти. Така не обмежувала свою діяльність суто мистецьким чи науковим пошуком. Чимало громадських діячів, політиків, письменників, митців докладали всіх зусиль для просвітницької діяльності. За умов імперського перебування саме вони популяризували українську культуру, а також тематику соборності України;

- Зважаючи, що попередні режими, під юрисдикцією яких перебували українські землі, доклали усіх зусиль, аби перешкодити формуванню української буржуазії, інтелігенція обох частин України виконувала просвітницьку роботу без стабільної фінансової підтримки. То є одна 3 головних особливостей вітчизняної історії культури;

- У світосприйняття загалу діяльність творчої меншості обох частин України вписувалась повільно й поступово, оскільки головна увага пересічного підданого стосувалися суто практичних питань. Однак просвітницька робота української інтелігенції спричинилась до усвідомлення необхідності формулювання власних політичних вимог, що призвело до появи політичних партій;

- Мало місце питання щодо відірваності від повсякденного життя прогресивної галицької чи наддніпрянської богеми. Попри цілеспрямовану активність, просвітницька робота українських інтелігентів гальмувалась громадянською незрілістю самих аграріїв. Селяни обох імперій насамперед дбали про власні практичні інтереси, як-от бути хазяями на «своїй землі». Розумінню власних прав і усвідомленню необхідності реалізації права на національну державу перешкоджали віковий консерватизм й заскорузлість мислення;

- Єдність інтересів інтелігенції обох частин України підтверджуються численними спільними проєктами, наприклад, діяльністю Наукового товариства імені Шевченка, журналу «Зоря», що став трибуною для літераторів, випуском жіночого альманаху «Перший вінок», а також численними контактами Театру Товариства «Руська бесіда» та відомих наддніпрянських драматургів, спільними науковими розвідками тощо. Подібні проєкти свідчать про усвідомлення важливості зазначених контактів;

- Спільна діяльність інтелігенції обох частин України по-різному вписувались у чинне законодавство. Конституційна Імперія Габсбургів на законодавчому рівні гарантувала вільне волевиявлення, право на власні переконання і навчання рідною мовою. Щодо Наддніпрянської України, то до 1882 року просвітницьку активність обмежував Емський указ, після нього - цензура;

- В обох частинах України були свої об’єктивні перепони результативності просвітницької роботи, що гальмувало усвідомлення та розбудову української соборності й єдності. У Наддніпрянській Україні цьому заважали офіційна політика русифікації, цензура, чинне законодавство. Окреме місце посідає конфесійний чинник, спекуляція на якому відчутно гальмувала формування національної свідомості населення Російської імперії. У Австрійській Україні офіційна політика самої імперії не створювала штучних перепон, од- 
нак у галичан були впливові опоненти - реакційна частина польської громади, а також заважало спричинене нею москвофільство.

Відтак культурний діалог, як предтеча української соборності, чекає на подальші дослідження, доопрацювання, переосмислення, а також розуміння його феномену на перетині ментально-історичних конструкцій в історичній динаміці, зважаючи на останні виклики XXI століття.

\section{Бібліографія}

Б. Грінченко - М. Драгоманов. (1994). Діалоги про українську національну справу. Джерела з історії суспільно-політичного руху в Украӥні 19-поч. 20 століття. Київ: Національна академія наук України. Інститут української археографіï. $288 \mathrm{c}$.

Тридиять українських поетес: антологія (1968) /Упорядк., вст. ст., приміт. Л. Міщенко. Київ: Радянський письменник. 294 с. (Серія Бібліотека поета).

Воля, засвідчена справами. Іван Лисяк-Рудницький про формування українського народу i нації. Відновлено 3: https://www.religion.in.ua/zmi/ukrainian_zmi/6218volya-zasvidchena- $\quad$ spravami-ivan-lisyak-rud̄nickij-proformuvannya-ukrayinskogo-narodu-j-naciyi.html

Грінченко, Б. Листи з України Наддніпрянської. Відновлено 3: http://litopys.org.ua/drag/drag206.htm

«Зоря» 1880-1897. (1988-1989). Систематичний покажчик змісту журналу. Львів: АН Української РСР, Львівська наукова бібліотека ім. В. Стефаника.

Рудницький, С. Украӥна з погляду політичної географії. Відновлено 3: https://zbruc.eu/node/51853

Семчишин, М. (1985). Тисяча років украйнської культури: історичний огляд культурного процесу: монографія. НьюЙорк: J. K. Print Center. 550 с. (Б-ка українознавства, т. 52)

Слобожаніна, Н. До 150-річчя Людмили Старищької-Черняхівської. Відновлено 3: https://old.uinp.gov.ua/news/do150-richchya-lyudmili-staritskoi-chernyakhivskoi

«Основа» (1907): журнал. Ч. 28. Річник II, Львів, 10 липня.

«Основа» (1907): журнал. Ч. 34. Річник ІІ, Львів, 21 серпня.

«Основа» (1907): журнал. Ч. 13. Річник II, Львів, 27 березня.

Шеремета, О., Шумлянський, В. Польські зловживання та украӥнське хрунівство як елементи виборчої системи в Австро-Угорській державі у 1873-1914 рр. Відновлено 3: http://lvivacademy.com/vidavnitstvo_1/visnyk15/fail/ Sheremeta,Shumljanskyj.pdf

\section{References}

B. Grinchenko - M. Drahomanov (1994). Dialohy pro ukrainsku natsionalnu spravu. Dzherela z istorii suspilno-politychnoho rukhu $v$ Ukraini 19-poch. 20 stolittia [Dialogues about the Ukrainian national case. Sources on the history of sociopolitical movement in Ukraine 19th to early 20th century]. Kyiv: National Academy of Sciences of Ukraine. Institute of Ukrainian Archeography. 288 p. [in Ukrainian].

Trydtsiat ukrainskykh poetes: antolohiia [Thirty Ukrainian poets: Anthology] (1968). Kyiv: Soviet writer 294 p. [in Ukrainian].

Volia, zasvidchena spravamy [Will, proven by deeds]. Ivan Lysiak-Rudnytsky about the formation of the Ukrainian people and the nation. Retrieved from: https://www.religion. in.ua/zmi/ukrainian_zmi/6218-volya-zasvidchena-spravamiivan- lisyak-rudnickij-pro-formuvannya-ukrayinskogonarodu-j-naciyi.html

Grinchenko, B. Lysty z Ukrainy Naddniprianskoi [Letters from Dnieper Ukraine]. Retrieved from: http://litopys.org.ua/drag/ drag206.htm

«Zoria» 1880-1897. (1988-1989) Systematic contents of the magazine. Lviv: Academy of Sciences of the Ukrainian SSR, Lviv Scientific Library. V. Stefanyk. [in Ukrainian].

Rudnytskyi, S. Ukraina z pohliadu politychnoi heohrafii. [Ukraine from the point of view of political geography]. Retrieved from: https://zbruc.eu/node/51853

Semchyshyn, M. (1985). Tysiacha rokiv ukrainskoi kultury: istorychnyi ohliad kulturnoho protsesu: monohrafia [Thousand years of Ukrainian culture: historical review of the cultural process: monograph]. New York: J.K. PRINT CENTER/ 559 p. [in Ukrainian].

Slobozhanina, N. Do 150-richchia Liudmyly StarytskoiCherniakhivskoi [To the 150th anniversary of Lyudmyla Starytska-Chernyakhivska]. Retrieved from: https://old. uinp.gov.ua/news/do-150-richchya-lyudmili-staritskoichernyakhivskoi

«Osnova» (1907): Magazine. Issue 28. Anniversary II, Lviv, July 10 [in Ukrainian].

«Osnova» (1907): Magazine. Issue 34. Anniversary II, Lviv, August 21 [in Ukrainian].

«Osnova» (1907): Magazine. Issue 13. Anniversary II, Lviv, March 27 [in Ukrainian].

Sheremeta, O., Shumlyansky, V. Polski zlovzhyvannia ta ukrainske khrunivstvo yak elementy vyborchoi systemy $v$ Avstro-Uhorskii derzhavi u 1873-1914 rr. [Polish abuses and Ukrainian crowns as elements of the electoral system in the Austro-Hungarian state in 1873-1914]. Retrieved from: http://lvivacademy.com/vidavnitstvo_1/visnyk15/fail/ Sheremeta,Shumljanskyj.pdf.

\section{Larysa Kushynska}

\section{Cultural dialogue of two Ukraines at the turn of the XIX-XX centuries}

Abstract. The article is devoted to the cooperation and creative contacts of intellectuals of both sides of Ukraine during the modernism times of the domestic renaissance. It analyzes the educational mission of our bohemians, their cultural and creative potential. Emphasized is the decisive role of the domestic intellectuals in formation of Ukrainian national self-awareness. The article makes note of the problem of identity of Ukrainian national culture in view of absence of the statehood, being mindful of the collegiality at the mental level and further embodiment of this idea into the works of art.

Keywords: cultural dialogue, national awareness, cultural and creative indicator, popularization of Ukrainian culture, scientific societies, creative contacts. 


\section{Кушинская Лариса Анатольевна \\ Культурный диалог Подавстрийской и Надднепрянской Украины на стыке XIX-XX столетий}

Аннотация. Статья посвящена сотрудничеству и творческим контактам интеллигенции обеих частей Украины на модернистском этапе отечественного возрождения. Анализируется просветительская миссия нашей богемы, ее культуротворческий потенциал. Отмечается решающая роль отечественной интеллигенции в формировании украинского национального самосознания. Обращается внимание на проблему идентичности украинской культуры ввиду отсутствия государственности и осознание соборности на ментальном уровне и дальнейшее воплощение этой идеи в художественных произведениях. Сотрудничество украинской интеллигенции, ее контакты, а также просветительская деятельность автором рассматриваются как решающий фактор и предтеча соборности Украины.

Ключевые слова: культурный диалог, национальное сознание, социальная память, культуротворческий фактор, популяризация украинской культуры, научные общества, творческие контакты, соборность Украины. 